Article

\title{
Coping with Stress: How Hotel Employees Fight to Work
}

\author{
Caiwei Ma ${ }^{1, *} \mathbb{0}$, Lianping Ren ${ }^{2}\left(\mathbb{D}\right.$ and Jingxin Zhao $^{3}$ \\ 1 Hotel Management Department, Shanghai Polytechnic University, 2360 Jin Hai Road, Pudong District, \\ Shanghai 201209, China \\ 2 Macao Institute for Tourism Studies, Colina de Mong-Há, Macao, China; everen@iftm.edu.mo \\ 3 Hilton Hotel Management (Shanghai) Co., Ltd. Beijing Branch, \#1501 Tower C1, Oriental Plaza, \\ 1 East Chang'an Avenue, Dong Cheng Disctirct, Beijing 100010, China; Jesse.zhao@Hilton.com \\ * Correspondence: caiweima@aliyun.com
}

Citation: Ma, C.; Ren, L.; Zhao, J. Coping with Stress: How Hotel

Employees Fight to Work.

Sustainability 2021, 13, 10887.

https://doi.org/10.3390/

su131910887

Academic Editors: Amelia Manuti,

Antonino Callea and Maria

Luisa Giancaspro

Received: 8 August 2021

Accepted: 28 September 2021

Published: 30 September 2021

Publisher's Note: MDPI stays neutral with regard to jurisdictional claims in published maps and institutional affiliations.

Copyright: (c) 2021 by the authors. Licensee MDPI, Basel, Switzerland. This article is an open access article distributed under the terms and conditions of the Creative Commons Attribution (CC BY) license (https:// creativecommons.org/licenses/by/ $4.0 /)$.

\begin{abstract}
Working in hospitality establishments involves high levels of stress, partially due to the antisocial shift rotations and the high levels of emotional labor needed. Unmanaged stress often leads to psychological and even physical diseases, which harm both individual career development and hotel operations. Thus, it is of great importance to identify effective stress coping strategies to maintain a sustainable hotel work force. Stress coping behavior varies among different demographics and generations. Commonly used stress coping scales were established almost 40 years ago, and under the context of daily events, and may not be applicable in today's hospitality context. Thus, this study was designed to investigate effective stress coping strategies among today's hotel employees. Data were collected from 470 hotel employees in 37 cities in China. The results identified 12 effective coping strategies that fell under three dimensions: distraction, sharing, and self-indulgence. The findings contribute to scholarly knowledge of stress coping. Managerial implications are also discussed.
\end{abstract}

Keywords: job stress; stress coping strategies; coping efficacy; hotel industry; emotional labor

\section{Introduction}

Having a stable workforce is a prerequisite for sustainable development in the hospitality industry. However, increased job stress is harming the workforce and endangering the sustainable development of this industry. Thus, stress coping strategies need to be adopted to reduce stress, because job stress contributes to sustainable work performance [1]. Hospitality jobs have long been ranked high on the list of stressful careers [2,3], which has negatively affected hotel recruitment. Labor shortage is a common problem that hotels throughout the world encounter. Moreover, hotels are competing not only for talent among themselves, but also with other employers within the luxury industry [4]. This competitive labor market leads to high turnover rates, which in turn increases the work burden of remaining hotel staff, resulting in higher stress experienced by them. Furthermore, Coronavirus Disease 2019 (COVID-19) has decimated the formerly booming hospitality worldwide. Numerous hotel staff have been laid off or furloughed. This has further worsened the stress levels associated with jobs in this industry [5]. Stress associated with COVID-19 reduces organizational trust, job satisfaction, and the self-esteem of hospitality employees. It also indirectly affects organizational commitments [6]. Therefore, it is crucial to understand how hospitality employees can cope with stress effectively to maintain stable work performance, to contribute to sustainable development of the hospitality industry.

Work-related stress is a topic that has been extensively addressed in business, education, and psychology. Many empirical studies have attempted to examine ways of dealing with stress. For example, self-regulation is a powerful resource for preventing stress [7]; learned skills and prevention programs have also been proven to reduce stress $[8,9]$. Many of these stress studies are on health [10], life events [11], or education [12]. However, hospitality is different from many other industries, in terms of its frequent rotations, high 
emotional labor requirements [13], and large ratio of females [3]. Accordingly, do the characteristics of hospitality jobs differentiate hoteliers' stress coping from other industries' employees? The two basic coping functions are known as emotion-focused coping and problem-focused coping [14]. Due to the high emotion involving the nature of hospitality, do hoteliers use emotion-focused coping more often than problem-focused coping?

Furthermore, commonly used stress coping scales were developed almost forty years ago. The global birth rate reduction and life expectancy prolongation processes are contributing toward population aging - a big issue, resulting in the workforce structure changing [15]. Information technology has had a major impact on the quality of our lives in recent decades. Social distancing and increased hygiene standards required due to COVID-19 restrictions have accelerated the application of high technology in the service area, including hotels. Hotel employees are communicating with each other in different ways, and they have different after-work lives. With this much change taking place in recent decades, it was necessary to conduct an investigation and provide updated knowledge in the proposed area.

The current study attempted to close the aforementioned knowledge gaps regarding job stress coping strategies in the hospitality industry, and provide an updated strategy list. The findings may allow both individuals and industry organizations to promote effective stress coping strategies, ultimately benefiting all stakeholders. The contribution is expected to be timely, considering the lingering pandemic situation, and the fact that the entire hospitality industry (and its work force) is suffering tremendously.

\section{Literature Review}

\subsection{Job Stress and Associated Consequences}

The U.S. Health and Safety Executive defines stress as "the adverse reaction people have to excessive pressures or other types of demand placed on them at work" [16] (p. 32). Researchers argue that "stress" is different from "pressure" [16]. Pressure can be positive and motivate people to improve their performance, whereas stress refers to excessive pressure resulting in unpleasant emotional experiences, such as anxiety, annoyance, anger, and sadness that affect the well-being of workers [17].

Many psychological and medical papers have confirmed that stress is associated with several mental and physical health problems [11]. Furthermore, empirical studies have demonstrated a negative linear relationship between stress and performance [18]. For example, job stress is a strong contributing factor for burnout, leave intention, and turnover [19]. It is significantly correlated with thoughts of leaving, and it accounts for $18 \%$ of the variance in real intentions of leaving [20]. Stress perception has a strong influence on job performance [20]. A survey among several tourism and hospitality organizations determined that both surface and deep acting strategies, by following organizational display rules of emotional labor, are related positively with burnout [21]. Stress is the single largest contributor to workplace absence and is associated with poor health and well-being, reduced productivity, and increased sickness absence when not managed appropriately [14].

\subsection{Stress and Hospitality Jobs}

Knowledge of stress derived from hospitality jobs remains scarce. Due to the business nature of hotel service, hotel employees are required to work long hours and different shifts, for instance weekend shifts, nightshifts, or during holiday periods [3]. These working hours are antisocial and physically demanding. This characteristic of hotel work heightens the stress of staff who have family responsibilities, especially women [3]. A large percentage of employees in hotels is female. One study shows that they easily become nervous and anxious in stressful situations [3]. Thus, solutions allowing for stress release of hotel employees are vital.

In addition, hotel services involve intensive direct contact with customers and demand a high level of emotional labor [13]. The nature of the hospitality service means closer 
emotional connections than other service sectors [22]. Various studies have illustrated how employees in hotels, especially those working at the frontline, have to manage their emotions to comply with hotel rules regarding guest services [23]. Negative emotions must either be suppressed or covered, and employees are expected to display positive expressions.

Lee and Madera [24], in a systematic review of emotional labor research in the hospitality and tourism literature in the past 30 years, observed that stress is the most examined mediator of emotional labor. Numerous studies have indicated that emotional labor leads to burnout and stress. Recent research conducted a quantitative study with frontline hotel staff in Hong Kong and determined that different generations handled emotional labor differently; "Generation X (1965-1981)," adopted genuine acting and emotional dissonance more often, whereas "Generation Y (1982-1994)" employed surface acting and deep acting more frequently [25].

\subsection{Stress Coping Strategies}

Stress coping has been a hot topic since the two basic functions of coping were uncovered, based on an investigation on 100 middle-aged participants dealing with stressful events in daily living: the regulation of distressing emotions (emotion-focused coping) and doing something to change the problem causing the distress (problem-focused coping) [13]. Stress coping was also studied as part of stress reduction $[8,26]$. Stress coping strategies refer to the strategies that an individual adopts to react cognitively or psychologically/biologically, to adapt to a stressful situation that demands adjustment $[9,27,28]$. Recognizing the negative effects of stress in employee turnover, productivity, and wellbeing, researchers have investigated stress coping strategies. Stress coping strategies are reported to moderate the relationship between the stress experienced and the adaptational outcomes [29].

\subsubsection{Categories of Stress Coping Strategies}

The best-known stress coping taxonomy in earlier literature was "the ways of coping checklist (WCCL)" [13]. Many later studies employed modified versions of the WCCL (please refer to Table 1 for key papers on stress coping strategies). Billings and Moors [30] stated that methods of coping include active cognitive, active behavioral, or avoidance. Active cognitive coping refers to attempts to manage the appraisal of the stressfulness of the event; active behavioral coping includes attempts to deal directly with the problem and its effects; avoidance coping refers to attempts to avoid actively confronting the problem or to indirectly reduce emotional tension, with behavior such as eating. Although several other approaches exist, for example, the situation-specific coping approach, the method-foci approach is the most common approach in the study of stress coping in many disciplines [29]. The widely used scale to indicate the way of coping is $0=$ not applicable, with 1 to 4 representing the frequency of using the way $(1=$ used somewhat to $4=$ used a great deal) [29]. However, the WCCL scales were too general and collapsed multiple coping methods [31]. Furthermore, factor validity is not stable when data are collected from different demographics [29]. In addition, clear focus, or definitions among the terms for methods, or foci, is lacking. This is a call for the refining of quantitative coping measures [31].

Edwards [31] posed an alternative model based on the cybernetic theory and previous research. He believed that perceived stress and desired results affected coping. Five new forms of coping were identified, namely "attempts to bring the situation into conjunction with desires, adjust desires to meet the situation (i.e., accommodation), reduce the importance associated with the discrepancy (i.e., devaluation), improve well-being directly (i.e., symptom reduction), and direct attention away from the situation (i.e., avoidance)" [31] (p. 18). Their comparison of the WCCL and the cybernetic coping scale (CCS) indicated that CCS was more measurable. 
Table 1. Key stress coping strategies discussed in prior studies.

\begin{tabular}{|c|c|c|c|}
\hline Author(s) (Year) & Study Context & Method(s) & Coping Strategies \\
\hline $\begin{array}{l}\text { Folkman and Lazarus } \\
(1980)\end{array}$ & $\begin{array}{l}\text { Stressful events of } \\
\text { daily living }\end{array}$ & $\begin{array}{l}\text { Interviews } \\
\text { Survey }\end{array}$ & $\begin{array}{l}\text { Two approaches to coping: problem-focused and } \\
\text { emotion-focused } \\
\begin{array}{ll}\text { - } & \text { Problem-focused coping } \\
\text { - } & \text { Defining the problem } \\
\text { - } & \text { Generating, evaluating, and selecting } \\
\text { - } & \text { potential solutions } \\
& \text { Attempting to cognitively reappraise the } \\
\text { - } & \text { Reducing ego involvement } \\
\text { - } & \text { Finding alternative channels of } \\
\text { - } & \text { gratification } \\
\text { - } & \text { Eeveloping new standards of behavior } \\
\text { - } & \text { Minimization } \\
\text { - } & \text { Selective attention } \\
\text { - } & \text { Avoidance } \\
\text { - } & \text { Distancing } \\
\text { - } & \text { Self-deception } \\
\text { - } & \text { Positive comparisons } \\
\text { - } & \text { Reality distortion }\end{array}\end{array}$ \\
\hline
\end{tabular}

Billings and Moors (1981)
Stressful events of daily living
Survey

- Methods of coping: active cognitive coping, active behavioral coping, and avoidance coping

- Focus of coping: problem or emotions

$\begin{array}{lll}\text { Folkman and Lazarus } & \text { Education } & \text { Experiments } \\ \text { (1985) } & \text { Survey }\end{array}$
- $\quad$ Problem-focused coping

- Emotion-focused coping

- Wishful thinking

- Distancing

- Emphasizing the positive

- Self-blame

- Tension reduction

- Self-isolation

- $\quad$ Mixed coping

- $\quad$ Seeking social support
- $\quad$ Problem-focused coping

- Emotion-focused coping

Solomon et al. (1990)

Stressful events of daily living

Survey

- Distancing

- $\quad$ Mixed coping

- $\quad$ Seeking social support
- $\quad$ Problem-solving

- Wishful thinking

- Advice-seeking

- Growth

- Minimize threat

- Seek support

- Self-blame 
Table 1. Cont.

\begin{tabular}{|c|c|c|c|}
\hline Author(s) (Year) & Study Context & Method(s) & Coping Strategies \\
\hline Edwards (1992) & & Theoretical & 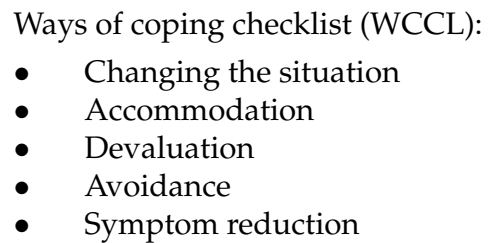 \\
\hline
\end{tabular}

Edwards and Baglioni (1993)

Work

Survey

Armour (1995)

Office work

Interviews

Peer pressure

- Openness

- Mutual goal
- $\quad$ Cybernetic coping scale (CCS)

- WCCL: confrontive coping, distancing, self-control, seeking social support, accepting responsibility, escape/avoidance, planned problem solving, and positive reappraisal.
Regulatory leisure coping:

- $\quad$ Planned-Breather Leisure Coping Style

- Avoidant Leisure Coping Style
Patry et al. (2007)

Education

Survey

Mohammadi et al.

(2008)

Education

Survey

Survey

Lind et al. (2010)

Health

Moradi et al. (2011)

Stressful events of daily living

Survey
- Efficient

- Non-efficient

- $\quad$ Refer to others
- $\quad$ Active coping

- Avoidance coping

- $\quad$ Depressive coping
- $\quad$ Problem-solving

- Social support-seeking

- Cognitive evaluation

- Somatic inhibition

- Emotional inhibition
Okamoto and Teo (2012)

Oversea work

Interviews
- $\quad$ Coping efforts

- Compliance

- Symptom formation

Tsaur and Tang (2012) Hospitality Survey

- Planned-breather leisure coping

- $\quad$ Avoidant leisure coping
Kondratyuk and

Morosanova (2014)

Hospitality

Survey
- Cognitive-appraisal coping

- $\quad$ Problem-solving coping

- $\quad$ Emotion-focused coping
Jung and Yoon (2015) Hospitality
Survey
- $\quad$ Cognitive-appraisal coping

- $\quad$ Problem-solving coping

- $\quad$ Emotion-focused coping 
Later research on stress coping generally involved attempts to further clarify and refine the dimensions of the WCCL and the CCS. Iwasaki [32] proved that leisure worked as one strategy to cope with daily stress and could contribute to well-being. It was further developed into two styles: the planned-breather leisure coping style (PBLCS) and the avoidant leisure coping style (ALCS) [12]. PBLCS combines both problem-focused and emotion-focused coping with a functional goal to reduce stress and stay positive. By contrast, ALCS is an escape tactic to either avoid or deny the stress [3]. Accordingly, active cognitive and active behavioral coping are combined into one method named "active coping" and split avoidance coping into "avoidance coping" and "depressive coping" [9]. Taking the above together, stress coping strategies in the existing literature can be summarized into the following figure (Figure 1).

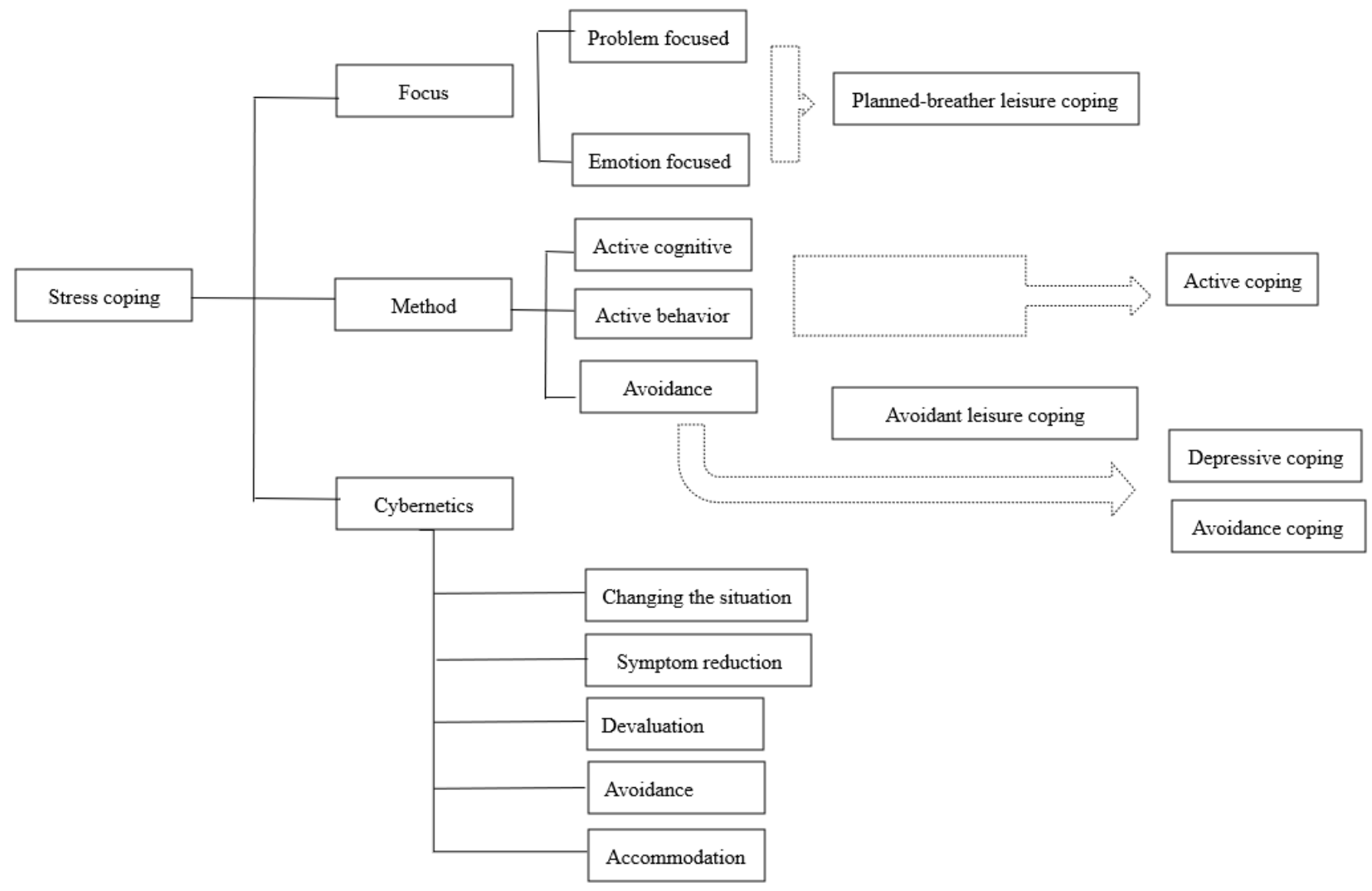

Figure 1. Stress coping strategies-a summary from the existing literature.

\subsubsection{Influential Factors for Effective Stress Coping}

Many factors can influence the stress coping process and the way it is conceptualized $[29,33]$. Work-related stressors are associated with increased problem-focused coping [13]. Based on the intelligence scale in the studies by Wu [18] and Schutte et al. [34], "intelligent" participants could recognize their emotions and undertake immediate mediating actions. Their studies proved that stress, when recognized, could be managed directly by individuals. More importantly, emotional intelligence can be enhanced through coaching or training $[16,35]$. Coping strategies have been proven to differ by gender $[30,36]$. Ursin and Eriksen [37] presented a cognitive activation theory and reported that handling situations with positive outcome expectancy elicited few complaints. Lind et al. [10] observed that the stress perceived by patients lessened when communication, leadership, and relocation strategies were used. Kondratyuk and Morosanova [7], after a study involving 242 participants, concluded that self-regulation might be a resource to prevent stress. Resource adequacy and availability also predict stress options [29]. 


\subsubsection{Stress Coping Efficacy}

One limitation of prior research concerns stress-release efficacy. Indeed, what influences subsequent coping behavior and outcomes is coping efficacy [29]. Several prior coping studies have indicated that a problem-solving strategy leads to positive results (e.g., job satisfaction), whereas an emotion-focused strategy leads to negative outcomes (e.g., depression) [12]. Other studies have proven that a combination of the two coping strategies stimulate a synergistic effect $[38,39]$. Researchers have reported that engaging in leisure activities can either enhance positive emotions or reduce negative emotions when one is faced with stress [3]. However, whether all leisure activities lead to the same level of stress reduction remains unknown.

In brief, stress coping varies by demography and situation [29]. Although stress coping strategies have been studied for years, the measures were mainly refined in the WCCL [13] and improved in the CCS [31], the validity of which may need to be assessed as time passes by and for different contexts. More importantly, these measures were based on frequency instead of effect, which may fail to address the efficacy issue. The review of the relevant literature has also identified a knowledge gap concerning the emotion labor and stress coping in the lingering pandemic situation. Thus, the present study explored the strategies perceived as effective in coping with job stress, nowadays, in the hotel context.

\section{Methods}

The purpose of this study is to identify effective stress coping strategies and determine the underlying dimensions, and ultimately develop a measurement scale. Thus, this study followed Churchill's [40] key steps for scale development, including instrument design (including item generation), and scale validation (exploratory factor analysis [EFA] and confirmatory factor analysis [CFA]).

\subsection{Item Generation and Instrument Design}

This stage was used to generate items to measure each of the specified constructs from the literature. An initial list of 33 items was generated from a review of relevant literature and exploratory semi-structured interviews. A total of 16 hotel staff from international hotel brands in Shanghai were invited to participate through snowball sampling-four from the human resource department, four from the food and beverage department, four from front office, three housekeeping, and the last one from the finance department. The purpose of the interviews was to uncover the specific characteristics of hotel staff stress coping behavior, as well as strategies and efficacy. Questions covered the following principal areas:

(1) Identifying job stress hotel staff experienced;

(2) Identifying hotel staff reactions to their experienced stress (strategies); and

(3) Self-evaluating the coping strategies they applied.

Nine staff were interviewed on a university campus upon completion of their work shift. Seven staff were interviewed with permission from their human resource directors in staff meeting rooms at their respective hotels during their off-peak work periods. The average duration of the interviews was $40 \mathrm{~min}$. All interviews were recorded with the approval of the interviewees and were transcribed verbatim shortly afterward. Transcripts were coded for analysis and were converted into items. Frequency counts produced a list of 33 items describing effective stress coping strategies. Eight items were eliminated due to ambiguity, redundancy, and false interpretation, resulting in a final 25-item inventory.

Face validity was assessed by an expert panel to modify the items for further data collection. This is vital, especially for studies containing proposed measurement items that were not previously established. Expert panels may include five to seven experts with professional research experience and publications in the content area, and may include experienced individuals who are good at the technology being studied [40]. The panel for this study comprised three hospitality academics and three human resource managers. Each expert examined the questionnaire and then offered their feedback to the researchers in person. 
Based on the feedback from the expert panel, one factor was modified: "watching movies" was expanded to "watching entertainment programs such as movies and TV shows." Table 2 presents the 25 items. Thirteen items have appeared in prior research, and the remaining twelve were newly generated from the interviews. Some of the newly identified items are described as follows: "waiting for the end of the day or week" is to hold the belief that one can relax after work; "following idol's blog" describes a staff member transferring focus from job stress to his/her favorite idol by looking at an idol's blog; "learning something new" refers to actively learning knowledge or skills to become better at one's job or career change; "accepting the situation" is to acknowledge and accept the reality of the work situation; "screaming out loud to release stress" refers to finding a closed room such as a dormitory or a spacious area, such as a park to scream aloud to reduce tension; "retreating to a quiet place" refers to staying alone in a quiet place to calm down; "adopting a new look" describes a hairstyle or makeup change to trigger inner enjoyment derived from the pleasing new appearance.

Table 2. Effective stress coping strategies from the literature and interviewing.

\begin{tabular}{lll}
\hline Items & Literature & Interview \\
\hline Comparing to worse & Billings and Moors, 1981 & $\sqrt{ }$ \\
Sleeping & Travers, 2011 & $\sqrt{ }$ \\
Eating & Folkman and Larazus, 1985 & $\sqrt{ }$ \\
Crying & Travers, 2011 & $\sqrt{ }$ \\
Saying alone & Folkman and Larazus, 1985 & $\sqrt{ }$ \\
Participating in sports & Folkman and Larazus, 1985 & $\sqrt{ }$ \\
Lifestyle change & Travers, 2011 & $\sqrt{ }$ \\
Venting to friends or relatives & Folkman and Larazus, 1985;Travers, & $\sqrt{ }$ \\
Sharing with hotel supervisor & 2011 & $\sqrt{ }$ \\
Sharing with colleagues & Folkman and Larazus, 1985 & $\sqrt{ }$ \\
Swearing & Folkman and Larazus, 1985 & $\sqrt{ }$ \\
Listening to relaxing music & Travers, 2011 & $\sqrt{ }$ \\
Traveling & Vyas and Luk, 2010; Yehuda, 2011 & $\sqrt{ }$ \\
Playing video games & Michael, Wien, and Reisinger, 2017 & $\sqrt{ }$ \\
Singing & - & $\sqrt{ }$ \\
Watching entertaining programs & - & $\sqrt{ }$ \\
Following idol's blog & - & $\sqrt{ }$ \\
Screaming out loudly & - & $\sqrt{ }$ \\
Taking deep breaths & - & $\sqrt{ }$ \\
Getting a massage & - & $\sqrt{ }$ \\
Adopting a new look & - & $\sqrt{ }$ \\
Shopping & - & $\sqrt{ }$ \\
Drinking alcohol & - & $\sqrt{ }$ \\
Sharing on social media & - & $\sqrt{ }$ \\
Writing diaries & - & $\sqrt{ }$ \\
\hline
\end{tabular}

The key research aim was to identify stress coping strategies perceived as effective; thus, the scale differs from those in prior studies. The following scale was used to measure the perceived effectiveness of strategies: $0=$ not used $/$ not applicable; $1=$ no perceived stress reduction at all; and 2 to 5 indicates low to high degrees of perceived stress reduction.

Apart from these items, the questionnaire included 10 demographic questions. The demographic questions involved gender, age, sibling, education, marital status, years of hotel work, hotel scale, type of hotel, job department, and job position.

\subsection{Data Collection and Analysis}

The questionnaire was distributed to hotel employees throughout China via the institutional collaboration network where the authors were based. The network included a few major hotel operators in China. An online survey was chosen for data collection. All questionnaire items were uploaded to the Chinese major online survey company, 
Sojump.com, and then the survey link was sent to either hotel human resource managers, with the permission from the universities/hotels, through emails.

To uncover the underlying dimensions of effective stress coping strategies, EFA was applied for initial data analysis, then followed by CFA to verify that the relationship between the observed variables and their underlying latent factor(s)/construct(s) exists [41] T-test and ANOVA were conducted to compare means among the three dimensions and detailed items.

\section{Results}

\subsection{Profile}

Altogether, 482 questionnaires were collected in two batches, from which 12 were deleted due to incompleteness. The demographic profiles demonstrated good diversity in terms of location, hotel type and scale, and gender. Table 3 illustrates the profile of participants. Hotel employees in 37 cities in different provinces of China joined the survey. The participants worked in various types of hotels (international $=275$; state-owned $=124$; private $=60$; other $=11)$. Luxury and upper scale hotels occupied $71 \%$ of the total, followed by upscale $(19 \%)$ and middle scale $(4 \%)$. The gender ratio was nearly equal (male $=257$; female $=213$ ). Overall, the respondents were young; $42 \%$ were 30 years of age or younger and $38 \%$ between 31 and 40 years old. The majority $(69 \%)$ had more than 3 years of hotel work experience. In terms of positions, $56.84 \%$ worked in frontline positions, $35.32 \%$ held middle level positions, and $7.87 \%$ held high management jobs.

Table 3. Profile of participants.

\begin{tabular}{|c|c|c|}
\hline Dimension & Category & Percentage $(\%)(n=470)$ \\
\hline \multirow[t]{2}{*}{ Gender } & Male & 54.68 \\
\hline & Female & 45.32 \\
\hline \multirow[t]{5}{*}{ Age } & $<30$ & 42.34 \\
\hline & $30-39$ & 38.30 \\
\hline & $40-49$ & 16.38 \\
\hline & $50-59$ & 2.77 \\
\hline & $>60$ & 0.21 \\
\hline \multirow[t]{2}{*}{ Sibling } & No & 48.72 \\
\hline & Yes & 51.28 \\
\hline \multirow{2}{*}{ Marriage } & Single & 35.11 \\
\hline & Married & 64.89 \\
\hline \multirow[t]{4}{*}{ Education } & High school & 31.7 \\
\hline & College diploma & 33.4 \\
\hline & Bachelor's degree & 33.19 \\
\hline & Master's degree or above & 1.70 \\
\hline \multirow[t]{9}{*}{ Department } & Housekeeping & 9.36 \\
\hline & Front office & 14.47 \\
\hline & $\mathrm{F} \& \mathrm{~B}$ & 36.17 \\
\hline & Spa and fitness & 1.49 \\
\hline & $\mathrm{HR}$ & 8.51 \\
\hline & Marketing and sales & 5.74 \\
\hline & Finance & 21.7 \\
\hline & Engineering & 3.83 \\
\hline & Security & 2.98 \\
\hline \multirow[t]{4}{*}{ Hotel scale } & Upper upscale and luxury & 71.28 \\
\hline & Upscale & 19.36 \\
\hline & Midscale & 4.68 \\
\hline & others & 4.68 \\
\hline
\end{tabular}


Table 3. Cont.

\begin{tabular}{ccc}
\hline Dimension & Category & Percentage $(\boldsymbol{\%})(\boldsymbol{n}=\mathbf{4 7 0})$ \\
\hline Type of hotel & State owned & 26.38 \\
& International & 58.51 \\
& Private & 12.77 \\
& Others & 2.34 \\
\hline Position level & frontline & 56.84 \\
& Middle & 35.32 \\
& High & 7.87 \\
\hline Years of working & $\leq 3$ years & 31 \\
& $>3$ years & 69 \\
\hline
\end{tabular}

In the item scales, " 0 " represents that the stress coping strategy was not used or not applicable. Thus, "frequency of adoption $=470-n$ " was used to count the frequency, with " $n$ " representing the number of non-uses of a stress coping strategy. The results are depicted in Figure 2. All of the collected 25 coping strategies were used by at least $62 \%$ of the 470 participants. Writing in a diary $(\mathrm{N}=446)$, sharing on social media $(\mathrm{N}=443)$, venting to friends or relatives $(\mathrm{N}=441)$, sharing with colleagues $(\mathrm{N}=435)$, sharing with a supervisor $(\mathrm{N}=432)$, and using curse words $(\mathrm{N}=423)$ were the most frequently used strategies $(90 \%)$.

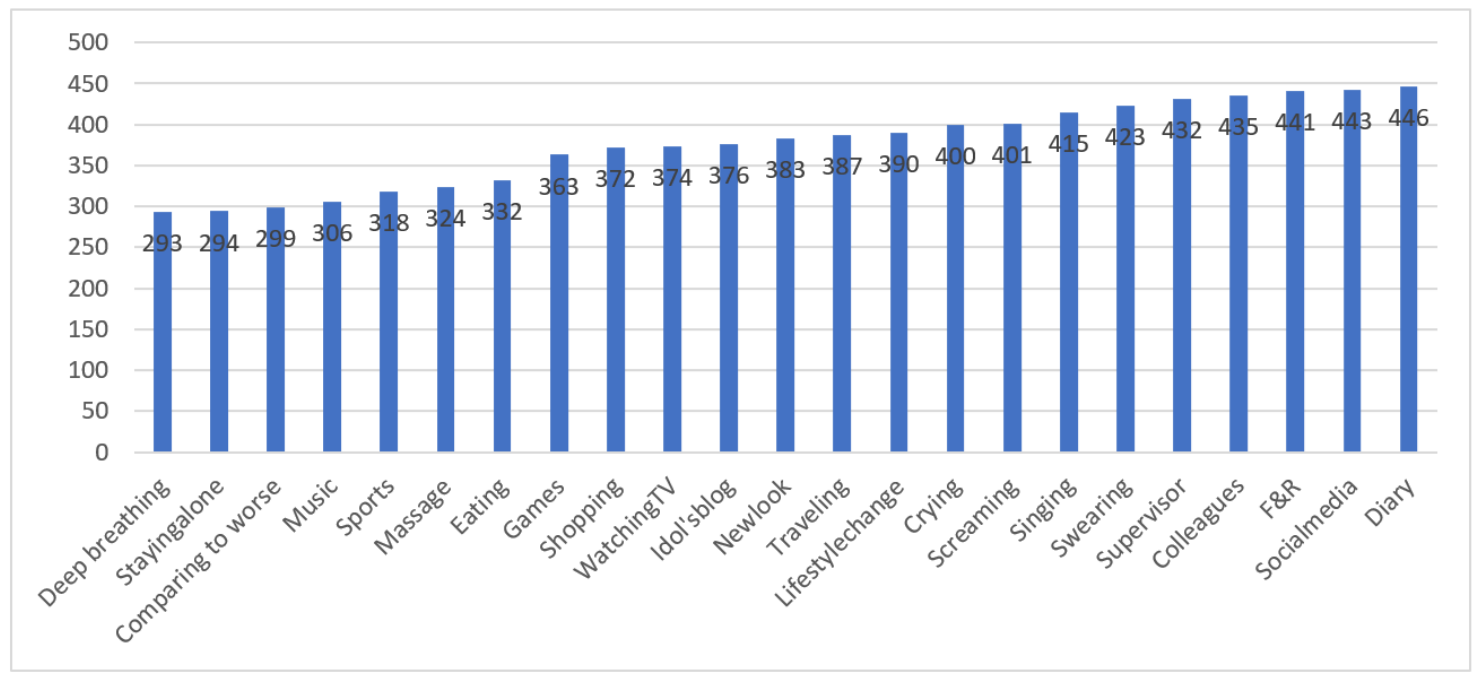

Figure 2. Frequency of stress coping strategies adopted.

\subsection{Exploratory Factor Analysis}

We evaluated the items through EFA to explore the underlying dimensions, using the first batch of data collected $(\mathrm{N}=235)$, specifically, principal component factor analysis with varimax rotation [41]. The final factor analysis resulted in three factors (12 items) with eigenvalues higher than 1.0 , explaining $65.741 \%$ of the total variance. Cronbach's alpha values for the three dimensions all exceeded the 0.50 cutoff value recommended by Nunnally [42]. The Kaiser-Meyer-Olkin value of 0.852 and a significant chi-square value for the Bartlett's test of sphericity $(x=1300.910, p<0.001)$ indicated that factor analysis was appropriate for the data. Table 4 presents the detailed results of the EFA.

The above dimensions failed to fall in any of the classifications in previous theories. Thus, renaming was performed based on each dimension's essence. Five items loaded on the first factor, which accounted for $28.446 \%$ of the total variance. The five items were shopping, visiting an idol's blog, adopting a new look, lifestyle change, and screaming aloud. The essence of these items suggests acting to focus less on work stress. Therefore, the first factor was named "distraction." The second factor had another five items loaded, 
namely sharing with a hotel supervisor, sharing with colleagues, venting to friends or relatives, sharing on social media, and writing a diary entry. All five items appeared to involve sharing and "letting out" what was disturbing them; thus, this factor was named "sharing," and it accounted for $22.601 \%$ of the total variance. The third factor included items somewhat different from the first two. They were drinking alcohol and playing video games, two things deemed indulgence behaviors, and this factor was named "self-indulgence." It accounted for $14.694 \%$ of the total variance.

Table 4. Dimension exploration $(\mathrm{N}=235)$.

\begin{tabular}{|c|c|c|c|c|c|c|}
\hline $\begin{array}{l}\text { Dimensions } \\
\text { and Items }\end{array}$ & $\begin{array}{c}\text { Cronbach's } \\
\text { Alpha }\end{array}$ & Communalities & $\begin{array}{c}\text { Factor } \\
\text { Loadings }\end{array}$ & $\begin{array}{l}\text { Item-to-Total } \\
\text { Correlation }\end{array}$ & Eigenvalue & $\begin{array}{c}\text { Variance } \\
\text { Explained (\%) }\end{array}$ \\
\hline Distraction & 0.838 & & & & 3.414 & 28.446 \\
\hline Shopping & & 0.540 & 0.735 & 0.586 & & \\
\hline $\begin{array}{l}\text { Following } \\
\text { Idol's blog }\end{array}$ & & 0.673 & 0.820 & 0.690 & & \\
\hline $\begin{array}{c}\text { Adopting a new } \\
\text { look }\end{array}$ & & 0.747 & 0.864 & 0.755 & & \\
\hline $\begin{array}{l}\text { Lifestyle } \\
\text { change }\end{array}$ & & 0.502 & 0.708 & 0.555 & & \\
\hline $\begin{array}{c}\text { Screaming out } \\
\text { loud }\end{array}$ & & 0.580 & 0.762 & 0.619 & & \\
\hline Sharing & 0.839 & & & & 2.712 & 22.601 \\
\hline $\begin{array}{l}\text { Sharing with } \\
\text { hotel } \\
\text { supervisor }\end{array}$ & & 0.684 & 0.827 & 0.691 & & \\
\hline $\begin{array}{l}\text { Sharing with } \\
\text { colleagues }\end{array}$ & & 0.743 & 0.856 & 0.728 & & \\
\hline $\begin{array}{l}\text { Venting to } \\
\text { friends or } \\
\text { relatives }\end{array}$ & & 0.608 & 0.780 & 0.637 & & \\
\hline $\begin{array}{l}\text { Sharing on } \\
\text { social media }\end{array}$ & & 0.550 & 0.741 & 0.602 & & \\
\hline Writing diary & & 5.07 & 0.712 & 0.574 & & \\
\hline $\begin{array}{c}\text { Self- } \\
\text { Indulgencing }\end{array}$ & 0.715 & & & & 1.763 & 14.694 \\
\hline $\begin{array}{l}\text { Drinking } \\
\text { alcohol }\end{array}$ & & 0.779 & 0.882 & 0.558 & & \\
\hline $\begin{array}{l}\text { Playing video } \\
\text { games }\end{array}$ & & 0.779 & 0.882 & 0.558 & & \\
\hline
\end{tabular}

KMO: 0.852; Chi-square: 1300.910; Sig.: 0.000; total variance explained: 65.741\%.

\subsection{Scale Validity}

The EFA results indicated good internal consistency and scale reliability. The next step was to validate the dimensions identified by the EFA results. A critical essential assumption in using AMOS is that the data are multivariate normal [43]. Thus, the normality of the collected data was assessed. First, univariate normality was checked. The univariate kurtosis value was smaller than 3 , which indicated a normal distribution. The index of skewness was within the absolute value of $2[44,45]$. Therefore, both skewness and kurtosis were in the acceptable range (Table 5).

AMOS 20 was used for scale validity analysis after normality assessment. The analysis consisted of two models: first-order and second-order. Both models were tested simultaneously in this study through structural equation modeling. Table 6 presents the initial CFA model. The model fit $\left(x^{2} / \mathrm{df}=2.326\right)$ was slightly higher than the cutoff point of 5.0; both goodness of fit (GFI) and comparative fit index (CFI) were greater than 0.90 $(\mathrm{GFI}=0.931 ; \mathrm{CFI}=0.953)$; the root mean square error of approximation (RMSEA) was 0.075 . This indicates that the general model fit was good. 
Table 5. Summary of normality test $(\mathrm{N}=235)$.

\begin{tabular}{|c|c|c|c|c|}
\hline Variable & Skew & c.r. & Kurtosis & c.r. \\
\hline $\begin{array}{l}\text { Playing video } \\
\text { games }\end{array}$ & -0.466 & -2.925 & -0.995 & -3.120 \\
\hline Drinking alcohol & -0.288 & -1.807 & -1.252 & -3.927 \\
\hline Writing diary & 0.083 & 0.520 & -1.569 & -4.919 \\
\hline $\begin{array}{c}\text { Sharing on social } \\
\text { media }\end{array}$ & -0.011 & -0.071 & -1.496 & -4.691 \\
\hline $\begin{array}{l}\text { Venting to } \\
\text { friends and } \\
\text { relatives }\end{array}$ & -0.673 & -4.222 & -0.647 & -2.030 \\
\hline $\begin{array}{l}\text { Sharing with } \\
\text { colleagues }\end{array}$ & -0.442 & -2.772 & -1.173 & -3.679 \\
\hline $\begin{array}{l}\text { Sharing with } \\
\text { supervisor }\end{array}$ & -0.107 & -0.671 & -1.514 & -4.747 \\
\hline Screaming & 0.105 & 0.656 & -1.564 & -4.906 \\
\hline Lifestyle change & -0.768 & -4.817 & -0.570 & -1.788 \\
\hline $\begin{array}{c}\text { Adopting a new } \\
\text { look }\end{array}$ & -0.462 & -2.899 & -1.084 & -3.399 \\
\hline $\begin{array}{l}\text { Following idol } \\
\text { blog }\end{array}$ & -0.148 & -0.930 & -1.397 & -4.381 \\
\hline Shopping & -0.668 & -4.189 & -0.498 & -1.563 \\
\hline Multivariate & & & 67.333 & 28.215 \\
\hline
\end{tabular}

Table 6. Initial confirmatory factor analysis.

\begin{tabular}{|c|c|c|c|c|c|c|c|c|}
\hline $\begin{array}{l}\text { Dimensions and } \\
\text { Items }\end{array}$ & & & Estimate & S. E. & CR & $p$ & Sd FL & SMC \\
\hline Shopping & $<-$ & Self-com & 1.000 & & & & 0.644 & 0.538 \\
\hline $\begin{array}{l}\text { Following Idol's } \\
\text { blog }\end{array}$ & $<-$ & Self-com & 1.420 & 0.143 & 9.934 & $* * *$ & 0.803 & 0.581 \\
\hline $\begin{array}{l}\text { Adopting a new } \\
\text { look }\end{array}$ & $<-$ & Self-com & 1.195 & 0.136 & 8.815 & $* * *$ & 0.684 & 0.620 \\
\hline Lifestyle change & $<-$ & Self-com & 1.000 & 0.126 & 7.949 & $* * *$ & 0.603 & 0.767 \\
\hline $\begin{array}{l}\text { Screaming out } \\
\text { loud }\end{array}$ & $<-$ & Self-com & 1.376 & 0.147 & 9.345 & $* * *$ & 0.737 & 0.356 \\
\hline $\begin{array}{l}\text { Sharing with } \\
\text { supervisor }\end{array}$ & $<-$ & Shar & 1.000 & & & $* * *$ & 0.769 & 0.426 \\
\hline $\begin{array}{l}\text { Sharing with } \\
\text { colleagues }\end{array}$ & $<-$ & Shar & 0.798 & 0.065 & 12.310 & $* * *$ & 0.653 & 0.591 \\
\hline $\begin{array}{l}\text { Venting to } \\
\text { friends or } \\
\text { relatives }\end{array}$ & $<-$ & Shar & 0.700 & 0.078 & 9.020 & $* * *$ & 0.596 & 0.543 \\
\hline $\begin{array}{c}\text { Sharing on social } \\
\text { media }\end{array}$ & $<-$ & Shar & 1.120 & 0.082 & 13.634 & $* * *$ & 0.876 & 0.364 \\
\hline Writing diary & $<-$ & Shar & 1.044 & 0.085 & 12.304 & $* * *$ & 0.787 & 0.468 \\
\hline Drinking alcohol & $<-$ & Indul & 1.000 & & & $* * *$ & 0.762 & 0.645 \\
\hline $\begin{array}{l}\text { Playing video } \\
\text { games }\end{array}$ & $<-$ & Indul & 0.926 & 0.124 & 7.477 & $* * *$ & 0.734 & 0.414 \\
\hline \multicolumn{9}{|c|}{$\mathrm{X}^{2}=111.648, \mathrm{df}=48, \mathrm{X}^{2} / \mathrm{df}=2.326, \mathrm{GFI}=0.931, \mathrm{CFI}=0.953, \mathrm{RMSEA}=0.075$} \\
\hline
\end{tabular}

Note: ${ }^{* * *}$ significant at $p<0.001$.

The standardized residual covariances indicated that some error terms created a considerably large covariance with modification indices greater than 20. For example, the error terms among "sharing with hotel supervisor", "sharing with colleagues", and "venting to friends or family" were highly related because these behaviors were related to talking to people around one. Thus, links among errors were created among these items based on the suggested modification indices and their substantive meanings. These modifications improved the model fit substantively; $\chi^{2}$ /df was reduced to 98.217 , GFI increased to 0.939 , CFI increased to 0.962 , and RMSEA decreased to 0.068 . The details are presented in Table 7. 
Table 7. Improved model of stress-release strategies.

\begin{tabular}{|c|c|c|c|c|c|c|c|c|}
\hline $\begin{array}{l}\text { Dimensions } \\
\text { and Items }\end{array}$ & & & Estimate & S. E. & CR & $p$ & Sd FL & SMC \\
\hline \multicolumn{9}{|l|}{ Distraction } \\
\hline Shopping & $<-$ & Self & 1.000 & & & & 0.676 & 0.457 \\
\hline $\begin{array}{l}\text { Following } \\
\text { Idol's blog }\end{array}$ & $<-$ & Self & 1.480 & 0.158 & 9.356 & $* * *$ & 0.801 & 0.641 \\
\hline $\begin{array}{l}\text { Adopting a } \\
\text { new look }\end{array}$ & $<-$ & Self & 1.254 & 0.149 & 8.442 & $* * *$ & 0.697 & 0.486 \\
\hline $\begin{array}{l}\text { Lifestyle } \\
\text { change }\end{array}$ & $<-$ & Self & 0.994 & 0.116 & 8.560 & $* * *$ & 0.601 & 0.361 \\
\hline $\begin{array}{l}\text { Screaming } \\
\text { out loud }\end{array}$ & $<-$ & Self & 1.452 & 0.162 & 8.939 & $* * *$ & 0.744 & 0.554 \\
\hline \\
\hline \multicolumn{9}{|l|}{$\begin{array}{c}\mathrm{AVE}=0.500 \\
\text { Sharing }\end{array}$} \\
\hline $\begin{array}{l}\text { Discussing } \\
\text { with hotel } \\
\text { supervisor }\end{array}$ & $<-$ & Shar & 1.000 & & & $* * *$ & 0.769 & 0.591 \\
\hline $\begin{array}{l}\text { Discussing } \\
\text { with } \\
\text { colleagues }\end{array}$ & $<-$ & Shar & 0.797 & 0.065 & 12.297 & $* * *$ & 0.651 & 0.424 \\
\hline $\begin{array}{l}\text { Venting to } \\
\text { friends or } \\
\text { relatives }\end{array}$ & $<-$ & Shar & 0.698 & 0.078 & 8.993 & $* * *$ & 0.595 & 0.353 \\
\hline $\begin{array}{l}\text { Sharing in } \\
\text { social media }\end{array}$ & $<-$ & Shar & 1.120 & 0.082 & 13.649 & $* * *$ & 0.876 & 0.767 \\
\hline $\begin{array}{c}\text { Writing } \\
\text { diary }\end{array}$ & $<-$ & Shar & 1.050 & 0.085 & 12.353 & $* * *$ & 0.790 & 0.624 \\
\hline \multicolumn{9}{|l|}{$\mathrm{CR}=0.858$} \\
\hline \multicolumn{9}{|l|}{$\begin{array}{c}\text { AVE }=0.552 \\
\text { Self- } \\
\text { indulgencing }\end{array}$} \\
\hline $\begin{array}{l}\text { Drinking } \\
\text { alcohol }\end{array}$ & $<-$ & Indul & 1.000 & & & $* * *$ & 0.761 & 0.580 \\
\hline $\begin{array}{c}\text { Playing } \\
\text { video games } \\
\mathrm{CR}=0.717\end{array}$ & $<-$ & Indul & 0.928 & 0.123 & 7.558 & $* * *$ & 0.734 & 0.539 \\
\hline $\begin{array}{c}\mathrm{CR}=0.717 \\
\mathrm{AVE}=0.559\end{array}$ & & & & & & & & \\
\hline \multicolumn{9}{|l|}{$\begin{array}{l}\text { Second- } \\
\text { order } \\
\text { model }\end{array}$} \\
\hline Distraction & $<-$ & $\begin{array}{l}\text { Effective } \\
\text { coping }\end{array}$ & 1.000 & & & $* * *$ & 0.998 & 0.996 \\
\hline Sharing & $<-$ & $\begin{array}{l}\text { Effective } \\
\text { coping }\end{array}$ & 1.159 & 0.168 & 6.902 & $* * *$ & 0.850 & 0.723 \\
\hline $\begin{array}{c}\text { Self- } \\
\text { indulgence }\end{array}$ & $<-$ & $\begin{array}{l}\text { Effective } \\
\text { coping }\end{array}$ & 0.933 & 0.154 & 6.066 & $* * *$ & 0.660 & 0.435 \\
\hline \multicolumn{9}{|c|}{$\mathrm{X}^{2}=98.217, \mathrm{df}=47, \mathrm{X}^{2} / \mathrm{df}=2.090, \mathrm{GFI}=0.939, \mathrm{CFI}=0.962, \mathrm{RMSEA}=0.068$} \\
\hline
\end{tabular}

Note: ${ }^{* * *}$ significant at $p<0.001$.

In the improved model, indices for construct reliability and validity suggested a good fit. All factor-loading values were above 0.50 and all critical ratio (CR) values were above 0.7 . The discriminant validity was also examined by comparing variable correlations [43]. The results (in Table 8 ) proved that the correlations between pairs of the variables passed the threshold $(<0.850)$.

Table 8. Correlations of CFA measurements.

\begin{tabular}{|c|c|c|c|}
\hline & Correlations & & \\
\hline & Distraction & Sharing & Indulgence \\
\hline Distraction & 1.00 & & \\
\hline Sharing & 0.828 & 1.00 & \\
\hline Indulgence & 0.653 & 0.558 & 1.00 \\
\hline
\end{tabular}




\subsection{Means Comparation}

The T-test results show that female and male hoteliers coped differently regarding distraction strategy and sharing strategy. Females perceived the effect of distraction $(\mathrm{M}=3.81)$ and sharing coping $(\mathrm{M}=3.37)$ better than males do $(\mathrm{M}=3.55, \mathrm{M}=3.20)$. More specifically, females perceived shopping $(\mathrm{M}=4.20)$, discussion with supervisor $(\mathrm{M}=3.31)$ and colleagues $(\mathrm{M}=3.62)$ more effective stress releasing strategies, while males like to cope stress by playing video games $(M=3.86)$. Other demographic groups did now show any statistically significant differences. Please refer to Table 9 for details.

Table 9. T-test.

\begin{tabular}{|c|c|c|c|c|c|c|c|c|}
\hline & & \multirow[t]{2}{*}{ Sample Size } & \multicolumn{2}{|c|}{ Dimension } & \multicolumn{4}{|c|}{ Items } \\
\hline & & & Distraction & Sharing & $\begin{array}{c}\text { Playing Video } \\
\text { Games }\end{array}$ & Shopping & $\begin{array}{l}\text { Discussing } \\
\text { with } \\
\text { Supervisor }\end{array}$ & $\begin{array}{c}\text { Discussing } \\
\text { with } \\
\text { Colleagues }\end{array}$ \\
\hline \multirow[t]{3}{*}{ Gender } & $\begin{array}{l}\text { T-value } \\
(\mathrm{df}=468)\end{array}$ & & $7.71 * *$ & $5.28^{*}$ & $13.65^{* * *}$ & $13.59^{* * *}$ & $5.36^{*}$ & $5.69^{*}$ \\
\hline & $\begin{array}{l}\text { Mean of } \\
\text { males }\end{array}$ & 257 & $3.55(1.22)$ & $3.20(1.29)$ & $3.86(1.45)$ & 3.59 (1.56) & 3.17 (1.65) & 3.39 (1.52) \\
\hline & $\begin{array}{l}\text { Mean of } \\
\text { females }\end{array}$ & 213 & $3.81(1.07)$ & $3.37(1.18)$ & $3.38(1.66)$ & $4.20(1.31)$ & $3.31(1.54)$ & $3.62(1.40)$ \\
\hline
\end{tabular}

${ }^{*}=p<0.05,{ }^{* *}=p<0.01,{ }^{* * *}=p<0.001$. Standard Deviations appear in parentheses after mean.

\section{Discussion}

The purpose of this study was to explore and test the effectiveness of individual stress coping strategies used by hotel employees. The results show that the stress coping scale generated in this investigation differs from commonly used stress coping scales $[13,30,31]$. Based on the nature of grouped items, the dimensions were "distraction", "sharing", and "self-indulgence." Previous research followed Folkman and Lazarus's studies to measure coping by frequency of use, whereas this study measured the perceived effectiveness of the various coping strategies adopted. That is, we focused on coping efficacy instead of frequency. The different measures used in this study lead to different findings from previous research.

\subsection{Distraction}

Five items are under the distraction dimension, which are shopping, following an idol's blog, adopting a new look, lifestyle change, and screaming aloud. Various studies have indicated that people often shop after a setback, to mentally "repair" their damaged experience with something more pleasurable, especially for women [46]. There are passive and active forms of shopping participation; the former involves relaxing and being entertained and the latter involves socializing and exploring. Items under "distraction" are generally forms of 'active action' used to distract oneself from work stress [47].

\subsection{Sharing}

The "sharing" dimension contains strategies to share the stressful issue, with either others or oneself, through verbal or textual expression, which includes sharing with a hotel supervisor, sharing with colleagues, venting to friends or family, sharing on social media, and writing in a diary. This study not only echoes previous stress coping studies by confirming that some previous literature proved sharing items (sharing with supervisors, sharing with colleagues, and sharing with family and friends) were still perceived as effective forms of coping by the participants, but also generates some new effective sharing strategies, such as diary writing and social media sharing. These new methods reflect changes in hotel employee behavior in the digital world. This finding also has to do with the ages of the participants: $80 \%$ were "Generation Y" (38\%) or "Generation Z (1995-)" (42\%).

Organizational or contextual factors (including social support and display rules) are the antecedents of emotional labor resulting in stress [48]. However, stress can be lessened 
when communication and leadership strategies are used [9]. In the current study, the "sharing" dimension included social support, such as sharing with supervisors/colleagues. This finding echoes that of Lam and Chen's [49] work, wherein social support from coworkers, the direct supervisor, and the organization may deliver advice, comfort, and concern to buffer employees against stressful events. In addition, a better work atmosphere among team members helps reduce stress [26].

The data were collected before and during the COVID-19 period. Tu et al. [5] examined the relationship between COVID-19-induced layoffs and survivors' COVID-19-related stress and performance in hospitality. They observed that a lack of support from family during COVID-19 moderates the relationship between employee's perceived stress and performance. Support from family members is valuable for individuals working under this special risk and high workload.

Social support heavily relies upon available sources [27]. By contrast, keeping a diary is fully under the control of individuals. Diary writing is a process of reflection that can lead individuals to more balanced views of a situation, i.e., through clarity of thought and emotional recognition [49]. Therefore, writing in a diary ranked first among all stress coping strategies. It is a process to recall and share the experience and feelings with oneself.

Social media sharing is another noteworthy behavior to release stress. Some scholarly investigations on young generations were devoted to the impact of technology on decisions, emotions, and preferred behavior [50,51]. Our results indicate that social media sharing ranked second in strategy use and was perceived by the participants as an effective (sharing) coping strategy. They were likely to post their feelings and thoughts on social media when in a stressful situation. This is in line with findings that young generations exhibit significant emotion gains from smartphone use [52].

Friends, family members, and celebrities are more influential on "Generation Zers" than they were with previous generations [48]. The results of the current study are consistent with this view; the participants liked to visit their idols' blogs when they felt stressed. Viewing an idol's blog ranked higher in frequency of use than other forms of entertainment, such as television. The development of the internet has brought fans closer to their idols and provided convenient, diverse, interactive portals for fan group activities [53].

\subsection{Self-Indulgence}

The statistics indicate that playing video games and drinking alcohol belong to another dimension apart from distraction, although they may appear similar to the term of distraction. These two stress-coping strategies contain meanings beyond distraction. Although both behaviors may alleviate stress effectively, they might lead to addiction if not handled properly. Over reliance on alcohol harms health; thus, it is frowned upon. Due to the high possibility of addiction to video games, especially among youth, playing video for extended time periods is not encouraged. Thus, we name these two items self-indulgence.

For centuries, people have used alcohol to relieve stress. Many participants who experienced stressful situations turned to alcohol to cope with that stress. According to Sayette's [54] study, however, drinking can only protect the drinker from fully experiencing a stressor. Alcohol consumption takes psychological and physiological tolls on the body and may actually compound the effects of stress. Drinking alcohol may seem to provide some relief-positive feelings and relaxation-in the short term, but as stressful events continue long-term, relief cannot be continuously hidden by alcohol. Regarding games, White [55] claimed that with colorful graphics, attractive characters, and challenging strategies, games are entertaining. Games can stimulate the prefrontal cortex, which is the "pleasure and reward" part of the brain. The gender difference among participants in China also echoes the situation in the U.S. According to a recent report from the Entertainment Software Association, 55\% of gamers in the U.S. are male, and among core gamers, males dominate.

Despite the scale differences, consistencies between our study's findings and those of prior studies were present. Some items in the sharing dimension, for instance, sharing 
with hotel supervisors/colleagues and venting to friends or family, are problem-focused behaviors, according to the scale designed by Folkman and Lazarus [13]. The remaining items could be considered emotion-focused or avoidance, based on their nature. Although problem-focused coping was proven to be a positive action against stress [27], most of our participants at hotels perceived emotion-focused coping as more effective. This finding might be connected to the emotional labor involved in hotel jobs. Hotel employees must comply with the rule to "treat guest friendly or even enthusiastically" [23]. This can result in emotional dissonance. One interviewee who works in the front office remarked, "I felt quiet tiring and stressful after smiling a whole day." However, the stress she felt was not derived from an actual problem and, thus, did not require problem-focused coping. As the findings indicate, emotion-focused coping, such as through shopping, may cure this type of stress. The participants were likely to comfort themselves for a time or even indulge in drinking alcohol or video-game-playing to release negative emotions.

\section{Conclusions, Implications, Limitations, and Future Research}

This study explored effective stress coping strategies among hotel employees. The dimensionality of each strategy was also explored. A mixed-methods approach consisting of three key procedures was adopted and resulted in a three-factor model containing 12 items. This study contributes to existing stress literature by identifying a three-factor scale on effective stress coping strategies (distraction, sharing, and self-indulgence), which contains an inventory of 12 factors (e.g., social media sharing, following an idol's blog). The results also indicate that hotel employee stress coping behavior evolves along with the development of information technology. This study also contributes to stress coping by measuring stress with perceived effect instead of frequency. Due to the characteristics of hospitality jobs, hoteliers use problem-focused coping ("sharing" in this study) more frequently to deal with work-related stress, but perceive emotion-focused stress coping more effective.

Managerial implications can be derived from the results. First, because distraction seems the most effective strategy for hotel employees seeking to reduce their stress, hotel managers are recommended to provide avenues for distraction. Examples can be providing more entertaining activities and creating functional areas that employees can retreat to. Second, hotels can provide employees with social support, such as by communicating constructive feedback, thus assisting them with completing their tasks. Empathy and care should also be expressed. With perceived fairness and respect, hotel employees are more likely to perform deep emotional acting instead of "fake" surface acting, which in turn reduces their stress. Managers are also encouraged to build a "free expression" work environment. Discussing one's inner feelings with colleagues reduces the negative influence of emotional labor on one's well-being [25]. Thus, hotel management can create sharing and feedback channels so that employees can share what they think and what they desire anonymously. Third, although drinking alcohol and playing video games are deemed indulgent behaviors, they are effective for hotel employees; thus, allowing them to do so on their own time is advised.

The study had two major limitations. First, the respondents mainly comprised frontline employees or low-level managerial staff in hotels. Because work stress felt by different levels of staff may differ greatly, future studies could include all staff levels. Second, the study was conducted in Mainland China, which inevitably generates the limitation of cultural singularity. Therefore, future studies might consider other cultural contexts.

Author Contributions: Conceptualization, C.M. and L.R.; methodology, C.M. and J.Z.; writing —original draft preparation, C.M.; writing—review and editing, L.R. and C.M. All authors have read and agreed to the published version of the manuscript.

Funding: Shanghai local university quality improving fund, Shanghai Polytechnic University Opening Branch (2021-2025). Grant Number: A30DB212103-0401.

Institutional Review Board Statement: Not applicable. 
Informed Consent Statement: Informed consent was obtained from all subjects involved in the study.

Data Availability Statement: The data presented in this study are available upon request from the corresponding author. The data are not publicly available due to privacy reasons.

Acknowledgments: The authors would like to thank all hoteliers for the data collection.

Conflicts of Interest: The authors declare no conflict of interest.

\section{References}

1. Rasool, S.F.; Wang, M.; Zhang, Y.; Samma, M. Sustainable work performance: The roles of workplace violence and occupational stress. Int. J. Environ. Res. Public Health 2020, 17, 912. [CrossRef] [PubMed]

2. Sarabakhsh, M.; Carson, D.; Lindgren, E. The personal cost of hospitality management. Cornell Hotel Restaur. Adm. Q. 1989, 30, 72-76. [CrossRef]

3. Tsaur, S.-H.; Tang, Y.-Y. Job stress and well-being of female employees in hospitality: The role of regulatory leisure coping styles. Int. J. Hosp. Manag. 2012, 31, 1038-1044. [CrossRef]

4. Bao, F. Empirical analysis of the hotel management student's satisfaction with their internship. J. Sichuan Tour. Univ. 2015, 3, $78-81$.

5. Tu, Y.; Li, D.; Wang, H.J. COVID-19-induced layoff, survivors' COVID-19-related stress and performance in hospitality industry: The moderating role of social support. Int. J. Hosp. Manag. 2021, 95, 102912. [CrossRef]

6. Kang, S.E.; Park, C.; Lee, C.-K.; Lee, S. The Stress-Induced Impact of COVID-19 on Tourism and Hospitality Workers. Sustainability 2021, 13, 1327. [CrossRef]

7. Kondratyuk, N.; Morosanova, V. The relationship between self-regulation, personality traits and job stress. Personal. Individ. Differ. 2014, 60, 48-78. [CrossRef]

8. Sylwester, R. The school as a stress reduction agency. Theory Pract. 1983, 1, 3-6. [CrossRef]

9. Stier-Jarmer, M.; Frisch, D.; Oberhauser, C.; Berberich, G.; Schuh, A. The effectiveness of a stress reduction and burnout prevention program-A randomized controlled trial of an outpatient intervention in a health resort setting. Dtsch. Ärzteblatt Int. 2016, 113, 781-788.

10. Lind, R.; Lillestol, K.; Valeur, J.; Eriksen, H.R.; Tangen, T.; Berstad, A.; Lied, G.A. Job stress and coping strategies in patients with subjective food hypersensitivity. Scand. J. Psychol. 2010, 51, 179-184. [CrossRef]

11. Moradi, A.; Pishva, N.; Ehsan, H.B.; Hadadi, P.; Pouladi, F. The relationship between coping strategies and emotional intelligence. Procedia Soc. Behav. Sci. 2011, 30, 748-751. [CrossRef]

12. Patry, D.A.; Blanchard, C.M.; Mask, L. Measuring University Students' Regulatory Leisure Coping Styles: Planned Breathers or Avoidance? Leis. Sci. Interdiscip. J. 2007, 29, 247-265. [CrossRef]

13. Chiang, F.F.T.; Birtch, T.A.; Kwan, H.K. The moderating roles of job control and work-Life balance practices on employee stress in the hotel and catering industry. Int. J. Hosp. Manag. 2010, 29, 25-32. [CrossRef]

14. Folkman, S.; Lazarus, R.S. An analysis of coping in a middle-aged community sample. J. Health Soc. Behav. 1980, 21, 219-239. [CrossRef]

15. Ivanová, E.; Grmanová, E. The sustainability of EU labor immigration in terms of poverty inequalities and employment. Sustainability 2021, 13, 2265. [CrossRef]

16. Roxane, G. Pressure release. Saf. Health Prac. 2015, 33, 32.

17. Anton, C. The impact of role stress on workers' behaviour through job satisfaction and organizational commitment. Int. J. Psychol. 2009, 44, 187-194. [CrossRef]

18. $\mathrm{Wu}, \mathrm{Y}$. Job stress and job performance among employees in the Taiwanese finance sector: The role of emotional intelligence. Soc. Behav. Personal. 2011, 39, 21-32. [CrossRef]

19. Azem, S.M.; Nazir, N.A. Role of stress and burnout among nurses in the private hospitals. Int. J. Acad. Res. Bus. Soc. Sci. 2014, 4, 420-428. [CrossRef]

20. Barak, M.; Nissly, J.; Levin, A. Antecedents to retention and turnover among Child welfare, social work, and other human service employees: What can we learn from past research? A review and metanalysis. Soc. Serv. Rev. 2001, 75, 625-661.

21. Prentice, C. Emotional labour and its consequences: The moderating effect of emotional intelligence. In Research on Emotion in Organizations; Zerbe, W.J., Ashkanasy, N.M., Hartel, C., Eds.; Emerald: Binglay, UK, 2013; Volume 9, pp. $187-201$.

22. Jain, R.; Jain, S. Towards relational exchange in services marketing: Insights from hospitality industry. J. Ser. Res. 2005, 5, 139-150.

23. Seger-Guttmanna, T.; Medler-Lirazb, H. Hospitality service employees' flirting displays: Emotional labor or commercial friendship? Int. J. Hosp. Manag. 2018, 73, 102-107. [CrossRef]

24. Lee, L.; Madera, J.M. A systematic literature review of emotional labor research from the hospitality and tourism literature. Int. J. Contemp. Hosp. Manag. 2019, 31, 2808-2826. [CrossRef]

25. Kucukusta, D.; Lim, Y.J. Emotional labor of frontline employees: Generational differences and intention to stay. J. China Tour. Res. 2020, 1, 1-23.

26. Armour, N.L. The beginning of stress reduction: Creating a code of conduct for how team members treat each other. Public Personal. Manag. 1995, 24, 127-136. [CrossRef] 
27. Folkman, S.; Lazarus, R.S. If it changes it must be a process: Study of emotion and coping during three stages of a college examination. J. Personal. Soc. Psychol. 1985, 48, 150-170. [CrossRef]

28. Jung, H.S.; Yoon, H.H. Understanding regulatory focuses: The role of employees' regulatory focus in stress coping styles, and turnover intent to a five-star hotel. Int. J. Contemp. Hosp. Manag. 2015, 27, 283-307. [CrossRef]

29. Oakland, S.; Ostell, A. Measuring coping: A review and critique. Hum. Relat. 1996, 49, 133-155. [CrossRef]

30. Billings, A.G.; Moos, R.H. The role of coping responses and social resources in attenuating the stress of life events. J. Behav. Med. 1981, 4, 139-157. [CrossRef]

31. Edwards, J.R.; Baglioni, A.J. The measurement of coping with stress: Construct validity of the ways of coping checklist and the cybernetic coping scale, Work \& Stress. Int. J. Work Health Organ. 1993, 7, 17-31.

32. Iwasaki, Y. Roles of leisure in coping with stress among university students: A repeated assessment field study. Anxiety Stress Coping 2003, 16, 31-57. [CrossRef]

33. Aldwin, C.M.; Revenson, T.A. Does coping help? A reexamination of the relation between coping and mental health. J. Personal. Soc. Psychol. 1987, 53, 337-348. [CrossRef]

34. Schutte, N.S.; Malouff, J.M.; Hall, L.E.; Haggerty, D.J.; Cooper, J.T.; Golden, C.J.; Dornheim, L. Development and validation of a measure of emotional intelligence. Personal. Individ. Differ. 1998, 25, 167-177. [CrossRef]

35. Salovey, P.; Mayer, J.D. Emotional intelligence. Imagin. Cogn. Personal. 1990, 9, 185-211. [CrossRef]

36. Pearlin, L.; Schooler, C. The structure of coping. J. Health Soc. Behav. 1978, 19, 2-21. [CrossRef] [PubMed]

37. Ursin, H.; Eriksen, H.R. The cognitive activation theory of stress. Psychoneuroendocrinology 2004, 29, 567-592. [CrossRef]

38. Lazarus, R.S. How emotions influence performance in competitive sports. Sport Psychol. 2000, 14, 229-252. [CrossRef]

39. Skinner, E.A.; Edge, K.; Altman, J.; Sherwood, H. Searching for the structure of coping: A review and critique of category systems for classifying ways of coping. Psychol. Bull. 2003, 129, 216-269. [CrossRef]

40. Churchill, G.A. A paradigm for developing better measures of marketing constructs. J. Mark. Res. 1979, 16, 64-73. [CrossRef]

41. Field, A. Discovering Statistics Using SPSS, 2nd ed.; Sage: Thousand Oaks, CA, USA, 2005.

42. Nunnally, J.C. Psychometric Theory, 3rd ed.; McGraw-Hill: New York, NY, USA, 1994.

43. Byrne, B.M. Structural Equation Modeling with AMOS: Basic Concepts, Applications, and Programming, 2nd ed.; Routledge: London, UK, 2010.

44. Garson, G.D. Testing Statistical Assumptions; Statistical Associates Publishing: Asheboro, NC, USA, 2012.

45. Kline, R.B. Methodology in The Social Scis: Principles and Practice of Structural Equation Modeling, 2nd ed.; Guilford: New York, NY, USA, 2005.

46. Why Does It Feel Good To Shop? Bustle. Available online: https://www.bustle.com/p/why-does-shopping-feel-good-44461 (accessed on 5 August 2021).

47. Sit, J.K.; Birch, D. Entertainment events in shopping malls-Profiling passive and active participation behaviors. J. Consum. Behav. 2014, 13, 383-392. [CrossRef]

48. Xu, S.T.; Zheng, Z.C.; Huo, Y. Antecedents and outcomes of emotional labour in hospitality and tourism: A meta-analysis. Tour. Manag. 2020, 79, 104099. [CrossRef]

49. Lam, W.; Chen, Z. When I put on my service mask: Determinants and outcomes of emotional labor among hotel service providers according to affective event theory. Int. J. Hosp. Manag. 2012, 31, 3-11. [CrossRef]

50. Travers, C. Unveiling a reflective diary methodology for exploring the lived experiences of stress and coping. J. Vocat. Behav. 2011, 79, 204-216. [CrossRef]

51. Priporas, C.-V.; Stylos, N.; Fotiadis, A.K. Generation Z consumers' expectations of interactions in smart retailing: A future agenda. Comput. Hum. Behav. 2017, 77, 374-381. [CrossRef]

52. Zhitomirsky-Geffet, M.; Blau, M. Cross-generational analysis of predictive factors of addictive behavior in smartphone usage. Comput. Hum. Behav. 2016, 64, 682-693. [CrossRef]

53. Zhuang, L. The influences of idol effect on the purchasing decisions of their fans. Adv. Econ. Bus. Manag. Res. 2018, 68, 165-171.

54. Sayette, M.A. Does drinking reduce stress? Alcohol Res. Health 1999, 23, 250-255. [PubMed]

55. White, L. Controlling the controller. In Shanghai Students' Post; Shanghai United Media Group: Shanghai, China, $2021 ;$ p. 1. 